\title{
Sacral and pubic insufficiency fractures due to bisphosphonate treatment
}

\author{
Bifosfonat tedavisine bağlı sakral ve pubik yetmezlik kırıkları
}

\author{
Tacettin Ayanaoğlu, MD, ${ }^{1}$ O. Şahap Atik, MD, ${ }^{1}$ Nil Tokgöz, MD, ${ }^{2}$ Murat Uçar, MD ${ }^{2}$ \\ ${ }^{1}$ Department of Orthopedics and Traumatology, Medical Faculty of Gazi University, Ankara, Turkey \\ ${ }^{2}$ Department of Radiology, Medical Faculty of Gazi University, Ankara, Turkey
}

\begin{abstract}
In this article, we describe a case of sacral and pubic insufficiency fractures related to long-term bisphosphonate therapy. Following termination of bisphosphonate therapy and tailoring a conservative treatment with calcium and vitamin $\mathrm{D}$, the fracture healing was observed.
\end{abstract}

Keywords: Bisphosphonate therapy; osteoporosis; sacral and pubic insufficiency fracture.

Insufficiency fractures may occur in abnormal bone under normal stress or following a low-energy trauma. Sacral insufficiency fractures are usually overlooked in the elderly. These patients have structurally weakened bones with low back pain and/or pelvic pain. There are reports indicating that long-term alendronate use may cause an increased susceptibility to fractures. ${ }^{[1,2]}$

Also, recent reports have suggested that a potential complication may be delayed union following atypical femoral fracture stabilization in patients taking longterm bisphosphonate. ${ }^{[3,4]}$

Herein, we report a case of sacral and pubic insufficiency fractures related to long-term bisphosphonate therapy who was treated with conservative treatment plus bisphosphonate discontinuation.

\section{CASE REPORT}

A 67-year-old woman was admitted with complaints of pain in left groin following low-energy trauma.
$\ddot{O} Z$

Bu makalede, uzun dönem bifosfonat tedavisine bağlı sakral ve pubik yetmezlik kırıkları olan bir olgu sunuldu. Bifosfonat tedavisinin sonlandırılmasının ve kalsiyum ve D vitamini ile konservatif tedavi verilmesinin ardından, kırık iyileşmesi gözlendi.

Anahtar sözcükler: Bifosfonat tedavisi; osteoporoz; sakral ve pubik yetmezlik kırığı.

She was on bisphosphonate therapy for four years. She used zolendronate for one year. Thereafter, she started alendronate for three years.

On physical examination, she was able to stand and walk with assistance. The pain was increasing gradually in the standing position, in particular. There was no pain with both active and passive hip motions. The hip joint had full range of motion on both sides. The straight leg raising test result was negative. Neurological examination findings were normal. The hip flexion-abduction-external rotation (FABER) test was painless. Sacroiliac compression and distraction tests were found to be positive.

On dual energy X-ray absorptiometry (DXA) of bone mineral density of the femoral neck and the lumbar spine, $\mathrm{t}$ scores of -2.1 and -4.1 were found, respectively. Bone scintigraphy showed a significantly increased osteoblastic activity on left sacroiliac joint. Magnetic resonance imaging (MRI) of sacroiliac joints revealed a prominent bone marrow edema on both sacral ala with associated vertically oriented

- Received: February 26, 2015 Accepted: May 25, 2015

- Correspondence: O. Şahap Atik, MD. Gazi Üniversitesi Tıp Fakültesi Ortopedi ve Travmatoloji Anabilim Dalı, 06500 Beşevler, Ankara, Turkey. Tel: +90 312 - 2025528 Fax: +90 312 - 2129008 e-mail: satikmd@gmail.com 


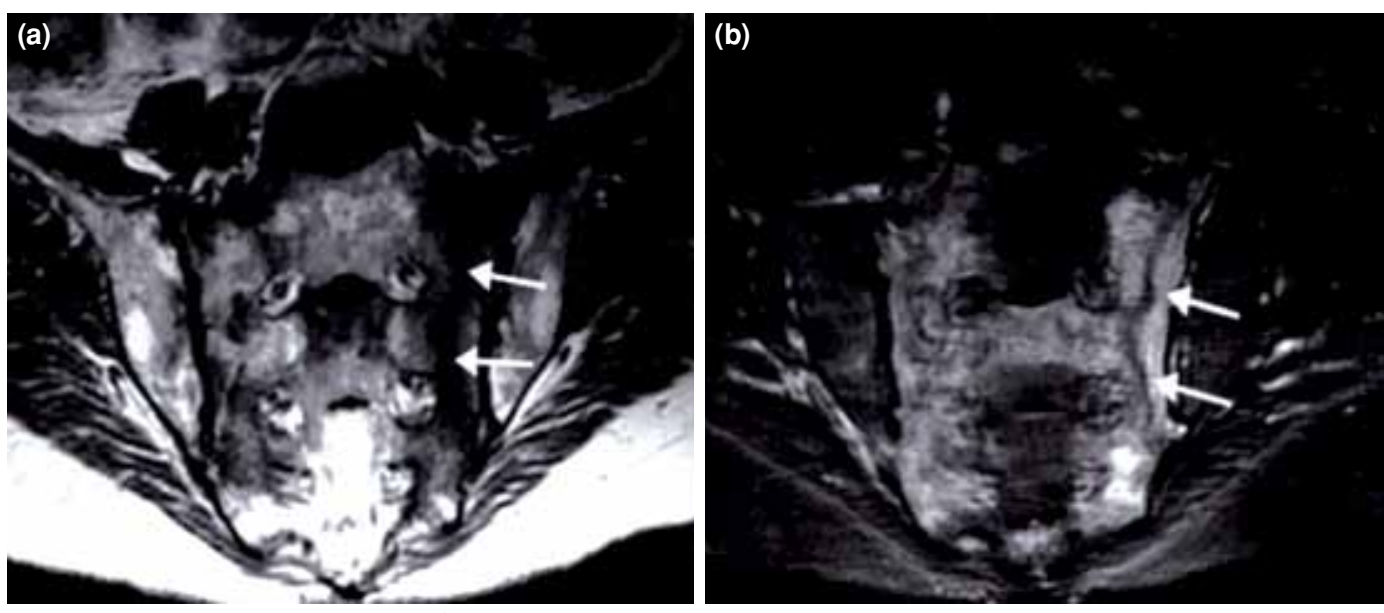

Figure 1. (a) $T_{1}$-weighted and (b) Short Tau Inversion Recovery coronal images showing left-sided vertically oriented fracture lines (arrows) and bilaterally medullary edema of the sacral ala.

fracture lines on the left side (Figure 1). Subsequent MRI examination of pelvic bone demonstrated an insufficiency fracture of pubic rami on the left side with associated prominent bone marrow and soft tissue edema (Figure 2). Based on the diagnosis of sacral and pubic rami insufficiency fractures, a conservative treatment including bed rest and paracetamol medication was initiated. Bisphosphonate therapy was discontinued. The complaints of the patient were regressed gradually in the following six weeks. Six months later pubic rami fracture healing was complete (Figure 3).

\section{DISCUSSION}

The exact incidence of sacral insufficiency fractures is still unknown due to misdiagnosis of other causes of pain and disability in elderly patients. In a twoyear prospective study by Weber et al. ${ }^{[5]}$ the incidence of pelvic insufficiency fracture in women aged over 55 years who were admitted to hospital with low back pain was $1.8 \%$.

Sacral stress fractures have been classified by Pentecost et al. ${ }^{[6]}$ into two groups: fatigue and insufficiency fractures. The fatigue fractures occur in healthy bones with abnormal or repetitive stresses, whereas insufficiency fractures occur in weakened bones under normal stress. Predisposing factors for insufficiency fractures include osteoporosis, radiation therapy, rheumatoid arthritis, fibrous dysplasia, osteogenesis imperfecta, osteomalacia, hyperthyroidism, and Paget's disease.

Furthermore, the clinical presentation of stress fractures is often variable. Patients are usually admitted with acute intractable low back or pelvic pain along with significantly reduced mobility without a history of
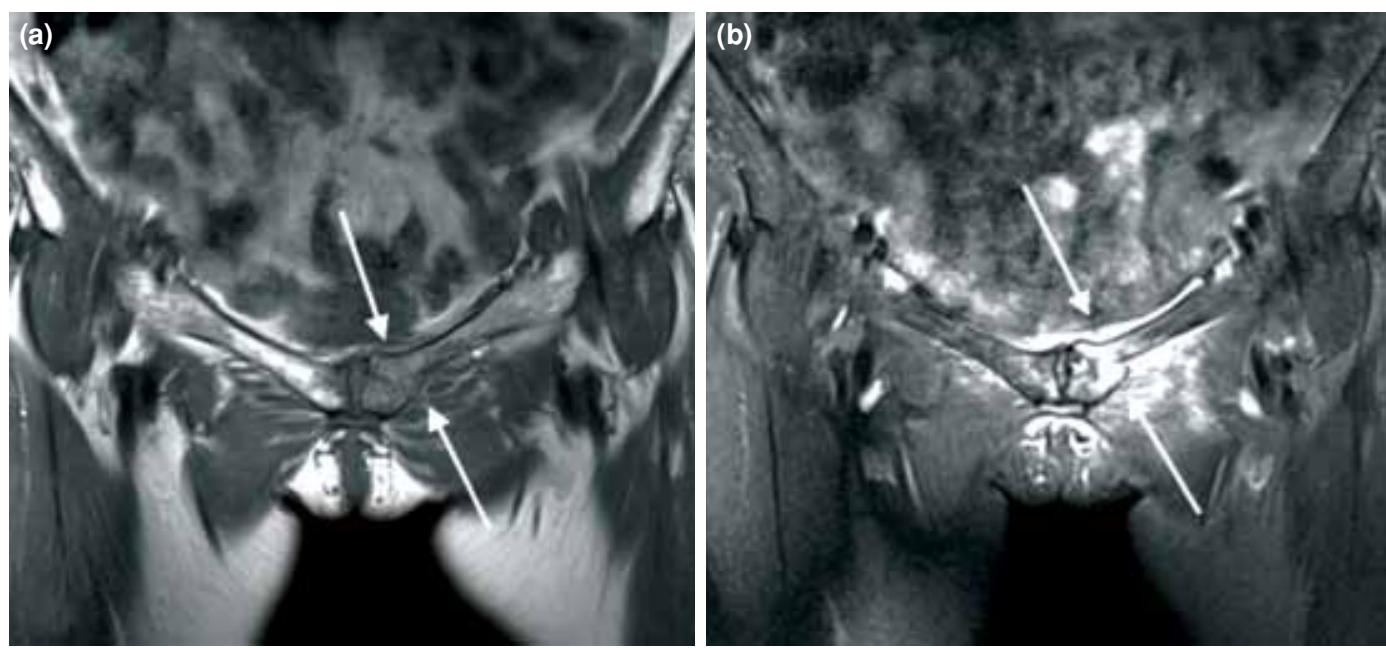

Figure 2. (a) $T_{1}$-weighted and (b) Short Tau Inversion Recovery coronal images showing left-sided insufficiency fracture of pubic rami (arrows). An associated medullary and soft tissue edema are present. 


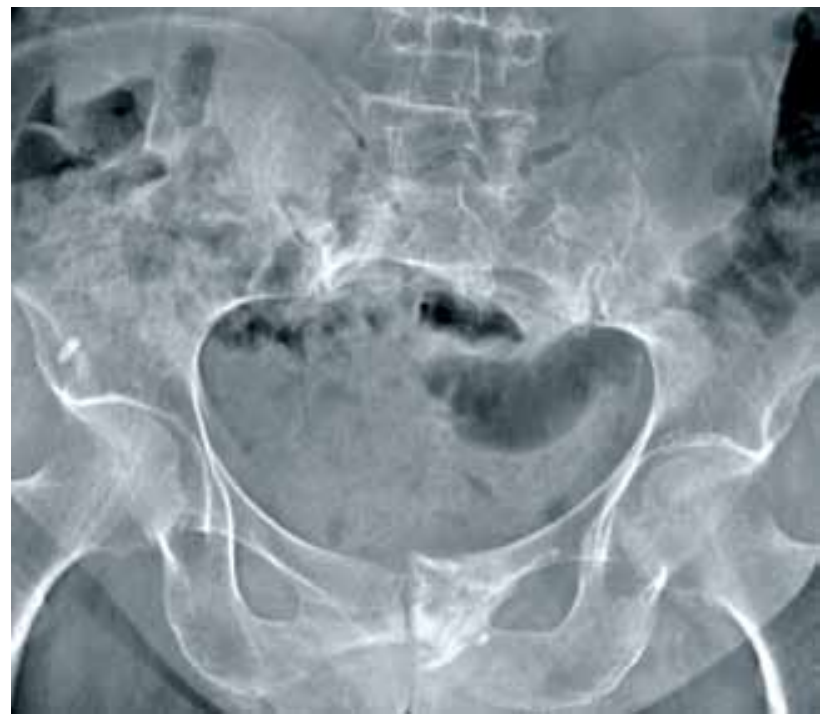

Figure 3. Rontgenogram showing complete healing of pubic rami fracture six months later.

trauma. Symptoms are exacerbated by weight-bearing activities, while they are relieved with rest and lying supine. Tenderness over the sacral area is common. Patients may present without any neurological symptoms. If the fracture involves the sacral body, neurological symptoms may occur in the form of radiculopathy, myelopathy, sphincter disturbance, and limb paresthesia. In case of tenderness over the parasymphyseal area and pain radiating to the groin, accompanying the pubic ramus fracture should be suspected. Aretxabala et al. ${ }^{[7]}$ reported that $78 \%$ of patients with sacral stress fractures had a coexisting pubic rami fracture. The disruption of the pelvic ring at one side may also increase stress on other parts of the ring itself, resulting in fractures. In our case, there were accompanied ipsilateral sacral and pubic rami insufficiency fractures.

Although X-ray can detect only complete fractures, anteroposterior and lateral radiographs of the pelvis, sacrum and lumbar spine are usually the first step imaging examinations. On the other hand, the presence of fecal material, vascular calcifications and bowel gas may mask the fracture line. According to several reports, MRI, which is the most sensitive and specific imaging method in bone marrow diseases, is considered as the gold standard in the diagnosis of sacral stress fractures. ${ }^{[8]}$ On sacral stress fractures, MRI shows intramedullary fractures which are best seen on $\mathrm{T}_{1}$-weighted images, as vertically oriented hypointense lines. The fracture lines can be seen hypointense or hyperintense on $\mathrm{T}_{2}$-weighted and Short Tau Inversion Recovery (STIR) sequences. Also, there are associated prominent bone marrow edema which is seen hypointense on $\mathrm{T}_{1}$-weighted, and hyperintense on $\mathrm{T}_{2}$-weighted and STIR sequences. Bone scintigraphy is extremely sensitive in the early diagnosis of sacral insufficiency fractures with a specific finding of $\mathrm{H}$-shaped sacral uptake pattern.

The majority of sacral insufficiency fractures are treated conservatively. Pain control is the first goal of the treatment of sacral insufficiency fractures. Paracetamol and opioids are used for analgesia. However, non-steroidal anti-inflammatory drugs are not recommended for the therapy of sacral stress fractures, due to the high risk of delayed union or nonunion.

In conclusion, osteoporosis treatment should be tailored after fracture healing is complete. Bisphosphonates, calcitonin, raloxifene, strontium ranelate, and recombinant human parathormone can be used for the treatment. Minimally invasive percutaneous procedures such as sacroplasty can be also performed in the treatment of painful fractures with limited morbidity and early mobilization. ${ }^{[9]}$ In the presence of instability or detectable motion at the fracture site or neurological defects or severe disruptions of sacrum alignment, osteosynthesis with surgical treatment can yield successful results. ${ }^{[10]}$

\section{Declaration of conflicting interests}

The authors declared no conflicts of interest with respect to the authorship and/or publication of this article.

\section{Funding}

The authors received no financial support for the research and/or authorship of this article.

\section{REFERENCES}

1. Atik OS, Suluova F, Görmeli G, Yildirim A, Ali AKh. Insufficiency femoral fractures in patients undergoing prolonged alendronate therapy. Eklem Hastalik Cerrahisi 2010;21:56-9.

2. Odvina CV, Zerwekh JE, Rao DS, Maalouf N, Gottschalk FA, Pak CY. Severely suppressed bone turnover: a potential complication of alendronate therapy. J Clin Endocrinol Metab 2005;90:1294-301.

3. Atik OS, Oztürk AM, Kunat C, Cetinkaya M, Kaptan Y. Do atypical femoral fractures in patients with prolonged alendronate treatment heal? Eklem Hastalik Cerrahisi 2014;25:52-5.

4. Grady MK, Watson JT, Cannada LK. Treatment of femoral fracture nonunion after long-term bisphosphonate use. Orthopedics 2012;35:e991-5.

5. Weber M, Hasler P, Gerber H. Insufficiency fractures of the sacrum. Twenty cases and review of the literature. Spine (Phila Pa 1976) 1993;18:2507-12. 
6. Pentecost RL, Murray RA, Brindley HH. Fatigue, insufficiency, and pathologic fractures. JAMA 1964;187:1001-4.

7. Aretxabala I, Fraiz E, Pérez-Ruiz F, Ríos G, Calabozo M, Alonso-Ruiz A. Sacral insufficiency fractures. High association with pubic rami fractures. Clin Rheumatol 2000;19:399-401.

8. Blake SP, Connors AM. Sacral insufficiency fracture. Br J Radiol 2004;77:891-6.
9. Sciubba DM, Wolinsky JP, Than KD, Gokaslan ZL, Witham TF, Murphy KP. CT fluoroscopically guided percutaneous placement of transiliosacral rod for sacral insufficiency fracture: case report and technique. AJNR Am J Neuroradiol 2007;28:1451-4.

10. Longhino V, Bonora C, Sansone V. The management of sacral stress fractures: current concepts. Clin Cases Miner Bone Metab 2011;8:19-23. 